\title{
Preservation of information in Sri Lanka: A historical perspective
}

\author{
Dehigama, K \\ Senior Assistant Librarian, University of Peradeniya, Sri Lanka \\ kanchanad@pdn.ac.lk
}

\begin{abstract}
The article attempts to explore the shape of preservation of information in Sri Lanka, from the Early Iron Age (1000-800 BC) to the beginning of Colonial Rule. Under the qualitative approach, the historical research method is employed in the study, while content analysis was used as a research tool to determine the presence of certain words, themes, or concepts within given qualitative data. Based on my focus, primary sources and secondary data were used to elicit data. Buckland's concept about information-asthing was used to streamline the demarcations made by different collections handled. The perspective of the study is limited to the published translations and transcriptions of inscriptions, literary sources, and copper plate charters. Themes and concepts such as selection of media, extending the life span of information, changing the format, or keeping the same information in different formats, and reformatting for information preservation emerged from the literature review and content analysis. Substantiations prove that effective preservation of information has ever been in flow in Sri Lankan history. Well before the cultural institutions were established under colonial rule, ancient Sri Lankans were familiar with the concepts of libraries, archives, and museums. Information was converted, reformatted, and duplicated through different media consciously, while foreign invasions, internal conflicts, natural and man-made disasters as well as the introduction of printing challenged the existence of the indigenous system of information preservation. The study will provide a rich foundation for Archaeology, history, and Information Science students and scholars to understand what happened in the past to determine and expand their research horizons. The research highlights gaps and avenues for future research in this genre.
\end{abstract}

Keywords: Preservation, Information, Palm Leaf Manuscripts, Inscriptions Sri Lanka, 


\section{Introduction}

The significance of preservation of information has ignited the interest and passion of most scholars and academics, especially in developed countries resulting in the development and implementation of actions and plans forming national policies and strategies in the recent past. Preserved Information contributes to validating memories and protecting the originality and authenticity of the document. As opposed to reproduction or surrogate, it draws people in and gives them a literal way of touching the past. Cloonan (2007), points out that preservation is more than a technical treatment but should be placed in a broader social and interdisciplinary context. While preservation has been a subject of interest during the 20th century, a probe into literature reveals that the concept of preservation is an age-old phenomenon. Many references to the idea of preservation are available in ancient literature. Spelman (2002, p.1) pointing out the preservation tendency of human beings describes "the Human Being is a repairing animal. Repair is ubiquitous, something we engage in every day and in almost every dimension of our lives. Homo sapiens also Homo reparans." This tendency in the preservation and providing access to information is also illustrated from Prehistoric times. Preserving of information by prehistoric man in the form of art, mostly in caves, have been interpreted as transmitting an educational or allegorical message for the benefit of future generations. Drawings that depict behaviour, killing or warning of animals in the milieu, method of collecting of food, etc. certainly, have aided other groups, clans, and posterity in making decisions in hunting and gathering. Three colour charcoal drawings (Figure 01) available at the walls of the Chauvet-Pont d'Arc Cave, in southeastern France, that illustrate more than 420 animals, graphic motifs, and symbols, are belonged to the early Aurignacian period dating to 30,00032,000 BP (Clottes, 2001; Azéma, \& Rivère, 2012). Figure 02 illustrates a cave art of smoking of a bees' nest to collect honey, in a site near the Toghwana dam in Matapo Hills, Zimbabwe (Pager, 1976; Crittenden, 2011). Information depicting elephant domestication in ancient Sri Lanka (Figure 03), is preserved in the Hulannuge rock cave in Ampara District (Nandadeva,1992). A point of access to 
prehistoric man's symbolic vision of the world is provided through the preservation of information on hunting sequences, daily events, and an element of their myths in these Paleolithic graphic narrations, (Fritz, \& Tosello, 2015).

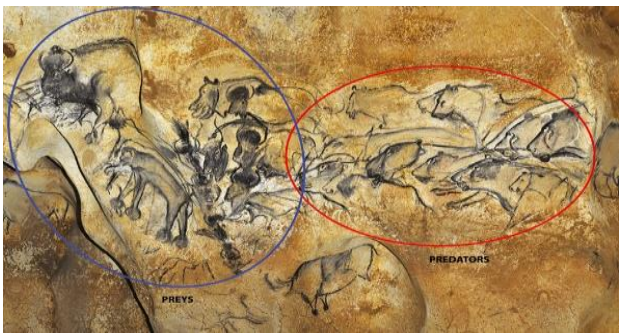

Figure 01

Hunting scene: big cats track a herd of bison fleeing toward the left. (Source: (Fritz, \& Tosello, 2015)

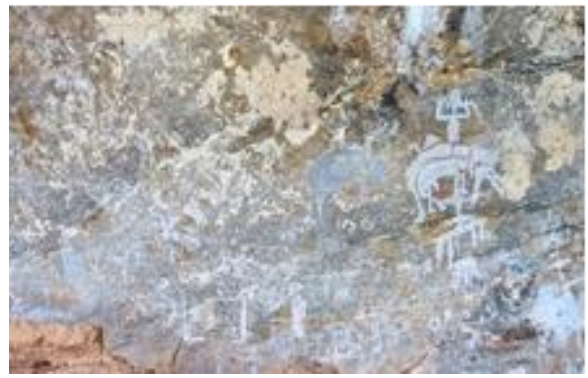

Figure 03

Source: https://amazinglanka.com

https://www.spurlock.illinois.edu,\& https://www.worldhistory.org/Egyptian_Literature/

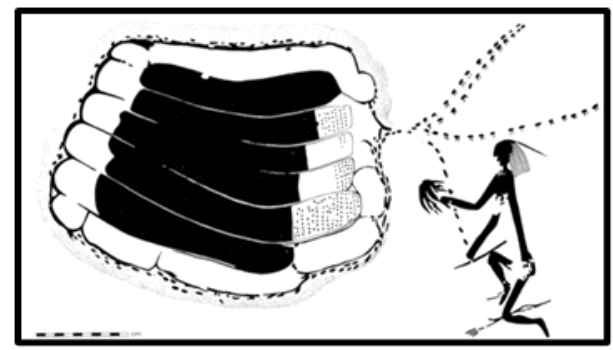

Figure 02

Smoking of a Bee's nest

Source: Pager, 1976; Crittenden, 2011

\section{Nature of the study}

"Before the mid-twentieth century, preservation referred to collecting. The very act of acquiring materials and placing them in an institution constituted preservation" (Cloonan, 2007, 132p. ). Later on, the Preservation of collections has become one of the core responsibilities of Memory Institutions (MIs) (Dempsey, 1999; Poll, 2010). It is commonly accepted that preservation and conservation were introduced to Sri Lanka with the establishment of MIs under colonial rule. However, a probe into literature provides ample evidence that well before the inception of MIs under colonial rule, ancient Sri Lankans were familiar with the concepts of preservation. Rulers, State Officials, Buddhist Monks as well as learned lay scholars played a 
major role in the preservation and conservation of ancient documents. These practices and regulations were mostly taken religious face. Even though Sri Lanka inherits a wealth of information depository since ancient times, thorough scrutiny into the previous research revealed that there is an apparent paucity of studies on preservation education and particularly on how information was preserved in ancient Sri Lanka. A probe into Sri Lankan preservation literature shows that there is an overarching trend of embracing digital technologies among MIs in Sri Lanka. Number of studies also emphasize that contemporary MIs of Sri Lanka drive toward reformatting of documents with special reference to digitization (for example Gangabadaarachchi and Amarasiri, 2009; Pushpakumara, 2007; Navirathan \& Jeyakanthan, 2018). Although, digitization is considered an inseparable part of preservation as it becomes the major method to safeguard the original (Manzuch, 2008), no research is available on the specific area of preservation of information particularly in ancient perspectives, which can provide a threshold to preservation studies in Sri Lanka. Hence the study is oriented to answer the question " what is the shape of preservation of information in ancient Sri Lanka?" The objective of the study is to explore ways and means of preservation of information from ancient times to introduce printing to Sri Lanka during the Colonial Period.

Under the qualitative approach, the historical research method is employed in the study, Historical research method is selected because the context under study is critical and provides the material for " immediate/direct and distant/indirect causes for chains of events they are documenting any length of time from a brief moment to events covering centuries or even millennia" (Porra, Hirschheim \& Parks, 2014). Content analysis was used as a research tool to determine the presence of certain words, themes, or concepts within given qualitative data which is expected to provide valuable historical and cultural insights over time analytically. Consequently, themes and concepts such as selection of media, extending the life span of information, changing the format, or keeping the same information in different formats that are more resistant to prevailing environmental conditions and reformatting emerged from the literature review and content analysis. 
Based on the focus of this study, primary and secondary sources such as ancient chronicles, inscriptions, literary sources, and charters were employed to elicit data. Since this study deals with varied informative materials, the term document is used based on Buckland's concept about information-as-thing. Considering the thingness-of information the term document is defined as "any source of information, in material form, capable of being used for reference or study or as an authority" (Buckland,1997) Accordingly, things are informative irrespective of the nature of materials such as massages, data, documents, objects, events, specimen record group or file. (Buckland, 1991; Ooghe \& Moreels, 2009). Use of this definition will streamline the distinctiveness made by different documents handled in this study.

By tracing the roots of information preservation and transmitting the information from past to future generations, the study will contribute to outline and define the history of the discipline, delineate its boundaries and understand core identity. The study will provide a rich foundation for Archaeology, History, and Information Science students and academics to understand what happened in the past to determine and expand their research horizons.

\section{Modes and Means of Preservation of Information}

\section{Bones and Clay}

Preservation has become a serious problem for the custodians of information throughout history since it is a complex and challenging process. Accordingly, more durable and movable materials were discovered for the preservation of information. Seals found at Indus Civilization (2500-1700 BC) (Figure 04-A), cuneiform clay tablets of Mesopotamia (3200 BC) (Figure 04-B) as well as Egyptian hieroglyphs (4000 BC) (Figure 04-C) explains the preservation concerns that go back to ancient times. In the Sri Lankan context, clay and stone were the two vastly used materials to preserve information in the forms of pots, bricks, seals, intaglios, caves, rocks, 
pillars, slabs, etc. Before the adoption of writing, identity marks of one clan or certain groups of communities were inscribed on pottery and drip-ledged caves, as well as on capstones of megalithic burials (figure 05) (Seneviratne, 1984). The Discovery of Early historic Bone stylus in the Anuradhapura Gedige excavation (Figure 06) heralds the history of the writing of Sri Lanka beyond the 1st century BC (Dereaniyagala, 1972). A much-debated post-firing potsherd which read as "Anuradi” was discovered from Anuradhapura by Dr Siran Deraniyagala through an excavation of Anuradhapura informs that written materials akin to Brahmi writing can be assigned to the third century BC (Deraniyagala, 1986). These writings are not only an indication of concerns paid over information preservation but also herald the challenging news that writing was in existence even before the advent of Buddhism to Sri Lanka. Brahmi and non-Brahmi letters, graffiti, and symbols incised on pottery throw light upon the fact that ancestors were concerned about the longevity of information. A Graffito of a vessel with a mast found in Akurugoda, Tissamaharama, (figure 07) has preserved centuries-old information to inform future generations about the knowledge of seafaring during the early periods (Weishaar, et. al. 2001).

$$
\begin{array}{ccc}
\text { S } \\
\text { Some of the symbols found in } \\
\text { Megalithic burials }
\end{array}
$$

Figure 05

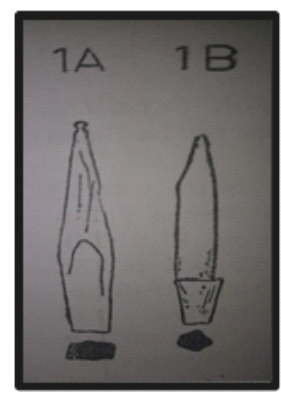

Figure 06
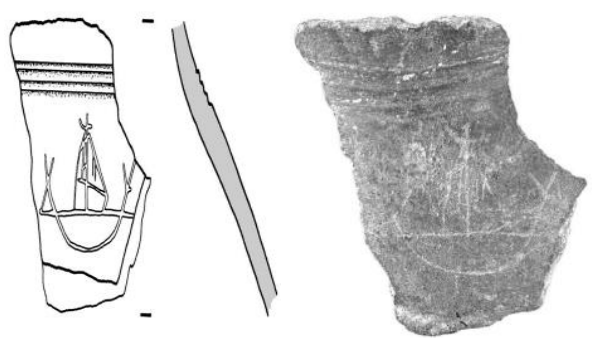

Figure 07

Figure 05 -Some of the symbols found in Megalithic burials, Source: Seneviratne, 1984 Figure 06 - Bone style from Anuradhapura Gedige Excavation, Source: Deraniyagala, 1972 Figure 07 - A Graffito of a vessel with a mast in Akurugoda, Tissamaharama, Source: Weishaar, et. al. 2001

\section{Stones: caves, slabs, and pillars}

In ancient Sri Lanka, the donation of drip ledge caves to the sangha was considered 
a significant event. Thus, information about the donor, the purpose of the donation, and attributes of the cave were also incised. Ancient Sri Lankans, by describing the distinctiveness of the particular cave, such as Manapadasane (of Pleasing View), Mahasudasane (of Great Good View), Manorame (that Delighting the Mind), painted caves (lapana), demonstrated their interest in preserving particular information inherent to the cave (Paranavitana, 1970).

Godawaya two-line stone inscription of King Gajabahu (113-135 A.D), which furnishes the details about the donation of customs duties of the port of Godapavata to the temple nearby is plausibly the oldest evidence on Customs duties in the entire world. However, there was no noticeable evidence of a seaport visible at the time of the discovery of the inscription. Hence, a series of archaeological explorations and excavations were carried out to verify the information. As a result evidence on an ancient port that had functioned from 2nd Century AD to 12th Century AD in Southern Sri Lanka at the old estuary of Walawe River was discovered. Thoughtful preservation of information in the form of an inscription facilitated filling a vital gap in Sri Lankan history, related to maritime links, international as well as internal trade (Weisshaar. et.al., 2001).

Ancient Kings were well aware of the significance of preservation Conservation activities as well as record keeping. Once a particular conservation work is completed, an inscription has been engraved to proclaim the news to the information of future generations. Polonnaruva Lankatilake Guard-Stone inscription of king Vijayabahu IV (1270-1272 A.D declares the conservation activities carried out in the temple (Wickremasinghe \& Codrington, 1933). Jetavanarama Sanskrit Inscriptions state when a person is assigned to supervise the temple renovation activities, the name of the person and his duties shall be recorded in the register known as pas-pot (Wickremasinghe, et. al.,1912). Slab-Inscription of the king Sahassamalla at Polonnaruva (1200-1202 AD) states that a declaration has been inscribed on a stone to let future kings not harm but to continue the grants as they are maintained during the time of the establishment of the inscription. (Müller, 
1915).

Information preserved in the Badulla Pillar Inscription of king Udaya IV (946-954 $\mathrm{AD}$ ), enlighten us on the preservation of administrative, trade, and socio-economic information in the 10th Century AD. It also informs us of the Officials those who are responsible for the information preservation of the state and concerns of lay countrymen on the recording and sustainability of information during the period. The inscription deals with a petition made to the king by merchants and residents of the market town of Hopitigamu against subordinate officials of the magistrate in charge of the market. Accordingly, officials had transgressed the orders enacted during the reign of the previous king, which were not been incised or not preserved in written form. After examining the grievances of the countrymen, the ruling king has passed a decree reinstating the regulations enacted by the previous ruler by inscribing an edict. The establishment of an Inscription in a public place providing public access to it leads to think that ordinary citizens of the country were well attentive to the preservation of information related to rules and regulations institutionalized in the written form. Also, the incident mentioned in the inscription highlights the rate of literacy among laymen was high as it was also depicted in the Sigiri Graffiti during the 6th century AD.

\section{Palm Leaves}

Although preservation of information on the stone was immensely used in the period, there was a requirement of using lengthy documents to store and preserve more extended information, especially during disasters. In early periods Buddha's teachings were preserved in oral form and transmitted from generation to generation. However, due to several natural and man-made challenges, the requirement of longterm preservation of Dhamma stood out prominently. Difficulties involved in the incision of lengthy documents, portability, mobility, and exertion in finding suitable stones might have led ancient Sri Lankans to seek alternative media. Under the patronage of kings and the guidance of Buddhist monks information that was in the form of Buddhist scriptures passed orally were documented in Palm Leaf 
Manuscripts (PLMs), in the 1st century BC (Geiger, 1908) The selection of Palm leaves as an appropriate medium for preserving information marked a turning point in Sri Lankan history. This decisive step would have been taken not only due to the difficulty of writing long Buddhist texts on stone but also perceiving the difficulty in protecting the authenticity of the orally transmitted knowledge. Kings enacted laws and regulations to safeguard the Palm trees while encouraging Palm gardens in the country.

Accounts on history including two main chronicles written in Palm leaves originally, such as Dipavamsa and the Mahavamsa, other literary sources, and artefactual information provide an account of the perceptions and practices followed in ancient Sri Lankan society. While some contend that the contents of these records are mostly Buddhist, the information preserved by these sources also delineates the socio-economic, political, cultural, and administrative history of the island.

In the meantime, the preservation of non-religious documents also has been augmented. Recording of non-religious texts on leaves is mentioned in inscriptions. Heart Hammillava rock inscription accordingly furnishes details about preserving monastery accounts by writing down on a leaf (kolahi liya tabava)( (Wickremasinghe, 1976). The word "kola" mentioned in the inscription according to Dias (2001) refers to a leaf, which was a common writing material in ancient Sri Lanka, that was Palm leaves

Two tablet inscriptions of King Mahinda IV (975-991AD) at Mihintale, provide further information about the thoughtful preservation of information in a Buddhist monastery of 11th century AD (Wickramasinghe, et. al., 1912). In addition to the information dealing with the administration and inner life of a Buddhist Monastery, these two tablets, preserve information on the emolument paid to the officials including a clerk of the monastery (Veher-leya), a registrar of the caskets (karandleya) and keeper of caskets(Karandu at-samu) who rendered services of preservation of information of the monastery. Accordingly, Officers were 
responsible for maintaining a register known as pas-pot to enter expenses on the renovation activities, expenditure on meals, costs related to revenue collectors. Documents where the accounts of the monastery were entered, was recommended to place in a casket under lock and key (ibid ) These caskets were instructed to deposit in the relic house, where reliquaries were deposited. The deposition of the registers [made of Palm leaves] that contained the accounts on the monastery in the relic house suggests the significance given by the ancestors to the preservation of information. They were well aware of the fragility and delicateness of the Palm leaves, as well as the significance of the information preserved in these documents. Thus, it was instructed to protect the balance sheets that were written on palm leaves in a more secure place. Inscriptions further state that the sheets of accounts that are secured in a casket shall be compiled at the end of each year; these balance sheets shall be made public by reading out amid the community of the monks. Authorities were very much concerned about the preservation of these documents, therefore, the inscription emphasized that the fines shall be imposed, and dismissal of service is recommended for the employees who infringe the above rules.

\section{Gold and Copper Plate Charters}

To achieve successful preservation practical measures must be established to ensure its survival against potential decay. Enduring the life of documents is significant because, in addition to their economical value, the fragility of documents prevents users from accessing original materials. This modern-day concept could be seen in ancient Sri Lankan practice, as recording information in Palm Leaves was replaced by the Copper plates in a later period of history.

King Nissankamalla (1187 to 1196 AD). in his Polonnaruwa slab inscription (Wickremasinghe, 1928) mentions that the decisive step of writing on Copper plates instead of Palm Leaves was initialized by him. There are previous instances that unveiled the availability of copper as well as gold plate inscriptions, however. Jetvanarama gold plate inscription, Abhayagiriya, Panakaduwa copper plate inscription, and a recent discovery of Dighavapi Gold Sheet inscription of king 
Kanittha Tissa (165-193 AD) appear before king Nissanka Malla period. However, King Nissankamalla was the foremost to particularly mention the reasons for the preservation of information on more endured materials instead of on Palm leaves. Accordingly, the Copper Plates were selected as a suitable medium to inscribe the grants due to their fragility of nature, and vulnerability to insects and rodent attacks over.

The life span of PLMs is rather shorter and vulnerable to natural and manmade disasters when compared to the other media chosen for the preservation of information. However, the inherent advantages of PLMs such as ease of mobility, portability, manageability as well as effortlessness of finding, led them selected as writing media. As a solution for its vulnerability to disasters and shorter lifetime alternative avenues were sought after. It proves that ancient Sri Lankans were well acquainted with the inherent strengths and weaknesses of each media. It is evident that registers that were known as pas-pot and lekam miti (land tenure registers) and other documents were maintained under the patronage of rulers throughout history. These documents later led to the development of a much organized Sri Lankan archival system under colonial rule in Sri Lanka.

\section{Conclusion}

The study investigated the shape of preservation of information in Ancient Sri Lanka through the evidence available from inscriptions, artefacts, PLM etc. it revealed that ancient Sri Lankans were concerned about every single incident and had taken measures to preserve information regarding the event. Despite the view that "until recent past preservation simply meant collecting and the coordinated and conscious management aspects of the preservation is more recent" (Conway, 1996), corroborations prove that effective preservation of information has ever been in flow in Sri Lankan history. Well before cultural institutions were established under colonial rule, ancient Sri Lankans were familiar with the concepts of libraries, archives, and museums and made attempts to preserve information embedded in 
different forms. Mahavamsa mentions that King Devanampiyatissa established a building in ancient Anuradhapura to safeguard the parts of the ship, which brought the sacred Bodhi tree from India in the 3rd century BC (Geiger, 1908) indicating about the world's oldest museum that preserved significant historic information. In the meantime, copies of important documents, have been deposited in the ancient chapter house Lovamahapaya, a nine-storied massive structure located between Ruvanveliseya and Sri Mahabodhi that played the role of the archive. Each Buddhist monastery has consisted of a library enabling, teaching, learning, and preaching. Concerns of the preservation of information were taken into account throughout history when even designing the buildings such as Tampita viharas (temples on pillars) during the Kandyan period.

While foreign invasions, internal conflicts, natural and man-made disasters as well as the introduction of printing challenged the existence of the indigenous system of information preservation, information was converted, reformatted, and duplicated through different media. Pottery, stones in the form of caves, pillars, slabs, etc., Palm leaves, Copper, Silver, and Gold plates were used to ensure the prolonged existence of documents over history very thoughtfully. As a result, a wealth of information ranging from the Early Iron Age (c. 1000-800 B.C) to until the beginning of printing during the Colonial rule was preserved in different materials Although the word preservation is not directly used in the ancient literary sources, the notion was practised in the ancient Sri Lankan Society in line with the presentday definitions of preservation. Hence the study concludes that recording and preservation of information in ancient Sri Lanka as a concept is positioned in tandem with the present-day preservation purposes, i.e. "the objective of preservation is to ensure that information survives in a usable form for as long as it is wanted" (Feather, 1996).

While exploring the shape of preservation of information in ancient Sri Lanka, names and duties of professionals involved in information preservation activities came across. historical sources bring together another silhouette of professionals 
engaged in preserving information till the end of the Kandyan kingdom. These officials are mentioned as scribes, chief secretaries and registrars and record keepers such as Mahale, Muk-hi, Mukaveti, Sanhals Sivatta Nayinarun, Sanhas Sivatteva Kala Perumal and Sannissiwatte Kulaperumal. It appears that this information provides access to a new arena for research on the history of Sri Lankan information preservation. However, there is no effort has been taken up to study, the role of ancient Sri Lankan professionals involved in the preservation of information. Avenues to new research rise through this information.

\section{References}

Amazing Lanka. (n.d). Hulannuge Thraulengala Rajamajaviharaya at Lahugala. Retrieved October 22, 2021, from https://amazinglanka.com/wp/hulan- nuge-tharulengala-rajamahaviharaya

Azéma, M., \& Rivère, F. (2012). Animation in Palaeolithic art: a pre-echo of cinema. Antiquity, 86(332), 316-324.

Buckland, M. K. (1997). What is a "document"? Journal of the American Society for Information Science, 48, 804-809.

Buckland, M. K. (1991). Information as thing. JASIS, 42(5), 351-360.

Cloonan, M. V. (2007). The paradox of preservation. Library Trends, 56(1), 133- 147.

Clottes, J. (2001). Chauvet Cave. National Geographic, 200(2), 104-121.

Conway, P. (1996). Preservation in the digital world. Washington, DC: Commission on Preservation and Access.

Crittenden, Alyssa N. (2011). The Importance of Honey Consumption in Human Evolution. Food and Foodways, 19 (4), 257-273.

Dempsey, L. (1999). Scientific, industrial, and cultural heritage: A shared approach. New review of information and library research, 5, 3-29. 
http://www.ariadne.ac.uk/issue22/dempsey!

Deraniyagala, S. U, (1972). The citadel of Anuradhapura in 1969: Excavations at Gedige area. Ancient Ceylon, 2, 48-169.

Dias, M. (Ed.). (2001). Inscriptions of Ceylon, vol. II, part II Containing rock and other inscriptions from the reign of Kanitthatissa (164 192 A.S.) to Mahasena (276-303 AD). Department of Archaeology, Sri Lanka

Feather, J. (1996). Preservation and the Management of Library Collections. Library Association Publishing Ltd.

Fritz, C., \& Tosello, G. (2015). From gesture to myth: Artists' techniques on the walls of chauvet cave. Palethnologie. Archéologie et sciences humaines, (7).

Gangabadarachchi, V., and Amarasiri, M.S.U. (2009). Digital collection building initiative of national library \& documentation centre. Sri Lanka journal of librarianship \&information management, 2 (1), 38-43.

Geiger, W. (Ed.). (1908). Mahavamsa: Great Chronicle of Ceylon (Vol. 63). Pali text society Manžuch, Z. (2011). Collaborative networks of memory institutions in digitisation initiatives. The Electronic Library 29(3), 320-343.

Müller, E. (1915). Epigraphia Zeylanica, Vol. II, Pts. I, II. By Don Martino de Zilva Wickremasinghe. Journal of the Royal Asiatic Society, 47(1), 167-172.

Nandadeva, B. D. (1992). Rock Art of Sri Lanka. Rock art in the Old world, IGNCA Rock Art series.

Navirathan, G., \& Jeyakananthan, M. (2018). Digitizing the Ceylon Collections: A Case Study of the Library, Eastern University, Sri Lanka. Journal of the University Librarians Association of Sri Lanka, 21(2).

Ooghe, B., \& Moreels, D. (2009). Analyzing selection for digitization: current practices and common incentives, D-Lib Magazine 15, 9-10. 
Pager, Harald (1976). Cave Paintings Suggest Honey Hunting Activities in Ice Age Times, Bee World, 57:1, 9-14.

Paranavitana, S. (Ed.). (1970). Inscriptions of Ceylon. Dept. of Archaeology, Sri Lanka.

Parpola, A. (1986). The Indus script: A challenging puzzle. World Archaeology, 17(3), 399419.

Poll, R. (2010). NUMERIC: Statistics for the digitization of European cultural heritage. Program: electronic library and information systems, 44(2), 122-131.

Porra, J., Hirschheim, R., \& Parks, M. S. (2014). The historical research method and information systems research. Journal of the Association for Information Systems, 15(9), 3.

Pushpakumara, K.T.S. (2007). A comparative study on use of digitization in university and special libraries of Sri Lanka, [Unpublished Masters thesis]. University of Colombo, Colombo, Sri Lanka.

Reitz, J. M. (2004). Dictionary for library and information science. Libraries Unlimited.

Seneviratne, S. (1984). The archaeology of the megalithic black and redware complex in Sri Lanka. Ancient Ceylon, 5(23), 7-30.

Spelman, E. V. (2002). Repair: The impulse to restore in a fragile world. Beacon Press.

Spurlock Museum of World Cultures. (n.d.). Cuneiform Clay Tablets. Retrieved October 23. 2021, from ttps://www.spurlock.illinois.edu/collections/searchcollection/details.php?a=1913.14.0550

Wickremasinghe, D. D. Z., \& Codrington, H. W. (Eds.). (1933). Epigraphia Zeylanica Vol. III 1928-1933. Asian Educational Services: New Delhi, India.

Wickremasinghe, D. M. D. Z. (Ed.). (1976). Epigraphia Zeylanica: Being Lithic and Other Inscriptions of Ceylon (Vol. 1). Government of Ceylon.

Wickremasinghe, D. M. D. Z., Paranavitana, S., Karuṇāratna, D. S., \& Codrington, H. W.(Eds.). (1912). Epigraphia Zeylanica: Being Lithic and Other Inscriptions of Ceylon (Vol. 


\section{1). The Rchaeological Department.}

Weisshaar, H. J., Roth, H., Wijeyapala, W., \& Depārtamēntuva, S. L. P. (2001). Ancient Ruhuna: Sri Lankan-German Archaeological Project in the Southern Province. von Zabern.

World History Encyclopedia.(n.d.). Ancient Egyptian Literature. Retrieved October 19, 2021 from https://www.worldhistory.org/Egyptian_Literature/ 